\title{
Taste aversion in mice using phencyclidine and ketamine as the aversive agents
}

\author{
FRANK ETSCORN and PATRICIA PARSON \\ New Mexico Institute of Mining and Technology, Socorro, New Mexico 87801
}

\begin{abstract}
Two potent dissociative anesthetics, phencyclidine and ketamine, were used to establish conditioned taste aversions in albino mice. Over the course of four preference tests, the ketamineinjected animals evidenced a slight extinction effect that did not occur in the phencyclidineinjected mice. The results are discussed in relation to prior phencyclidine taste aversion research using rhesus monkeys.
\end{abstract}

In rats, for example, palatable foods are subsequently avoided if initial consumption is conditionally paired with toxicosis induced from such means as $\mathrm{x}$-irradiation (Garcia, Kimeldorf, \& Koelling, 1955), drug injection (Garcia \& Koelling, 1967), or vestibular stimulation (Braun \& McIntosh, 1973). Although conditioned taste aversions (CTAs) have been the focal point of a great deal of learning research, others (e.g., Berger, 1972; Cappell \& LeBlanc, 1977) are currently investigating the aversive consequences of frequently abused drugs using the CTA paradigm with drug doses that are considered low enough to be nontoxic in typical behavioral assessments of drug toxicity (e.g., schedule-controlled behavior). Drug assessment studies using the CTA paradigm have obtained aversions with such drugs as alcohol (Nachman, Lester, \& LeMagnen, 1970), chlordiazepoxide (Cappell, LeBlanc, \& Endrenyi, 1973), cocaine (Goudie, Dickins, \& Thornton, 1978), d-amphetamine and mescaline (Cappell \& LeBlanc, 1971), and delta-8 and delta-9 tetrahydrocannabinol (Corcoran, Bolotow, Amit, \& McCaughran, 1974), as well as hashish (Corcoran, 1973) and morphine (Farber, Gorman, \& Reid, 1976).

Virtually unstudied in the CTA paradigm, however, are the so-called "dissociative anesthetics," such as phencyclidine and ketamine. These nonnarcotic, nonbarbiturate agents are termed dissociative in the sense that during induction, humans report feelings of dissociation from their environment (Goodman \& Gillman, 1975).

Phencyclidine produces an anesthesia with little effect on cardiovascular or pulmonary function; however, in early clinical trials, emergence from phencyclidine anesthesia was often complicated by several adverse reactions. These included psychotomimetic as well as pressor reactions of such magnitude that phencyclidine was abandoned for human use in 1965. The drug was remarketed beginning in 1969, under the trademark Sernyl ${ }^{\circledR}$, as an anesthetic agent for use in veterinary medicine, particularly subhuman primates.

Reprints may be obtained from Frank Etscorn, Department of Psychology, New Mexico Institute of Mining and Technology, Socorro, New Mexico 87801.
Incidentally, and due to its hallucinogenic properties, phencyclidine has become a drug of widespread illegal production as well as abuse (Allen \& Young, 1978; Eastman \& Cohen, 1975; Kessler, Demers, Berlin, \& Brennan, 1974; Liden, Lovejoy, \& Costello, 1975; Rainey \& Crowder, 1974).

Phencyclidine was followed by the development of a pharmacologically and chemically similar compound, ketamine. Clinically, this drug often produces hallucinogenic emergent reactions, however, it was nevertheless approved for human use.

Previous work (Wilcoxon \& Etscorn, Note 1; Wilcoxon, Etscorn, Czaplicki, \& Drake, Note 2) has suggested that phencyclidine at an intensity of $1 \mathrm{mg} / \mathrm{kg} \mathrm{IM}$ in rhesus monkeys may be an ineffective dose or drug for conditioning visual or taste-mediated aversions, the former cue being blue- or yellow-tinted water, the latter, sucrose solution with two-choice preference tests used for determining aversions. Parenthetically, aversions were conditioned in single-animal pilot studies using, for example, a sucrose taste cue and $64 \mathrm{mg} / \mathrm{kg} \mathrm{IM} \mathrm{LiCl}$ and using oral consumption of $.23 \mathrm{M} \mathrm{LiCl}$ with subsequent preference tests offering sucrose solution or plain water for the first pilot and a choice of a similar-tasting $\mathrm{NaCl}$ solution or a sour $\mathrm{HCl}$ solution for the second pilot. While the 1-mg dose of phencyclidine could possibly be considered too low for successful aversion conditioning, the duration of drug-induced debilitation lasted for approximately $3 \mathrm{~h}$ (with no emesis observed), suggesting that the animals were indeed sufficiently drugged.

A complete understanding of the behavioral responses to such drugs may be aided by determining the aversive consequences of typical doses using the CTA paradigm. To this end, the following study attempted to assess the ability of phencyclidine and ketamine to induce taste aversions following a single conditional pairing of a novel taste with a delayed drug injection.

\section{METHOD}

Subjects

Swiss-Webster-derived albino mice were selected as the 
subject species. The mice were born and raised in the psychology department animal colony (New Mexico Institute of Mining and Technology) and, following weaning, they were allowed ad-lib tap water and Purina Mouse Chow in group cages of approximately 15 per cage. For the experiment, 48 mice (60 days old, 24 of each sex) were assigned at random to individual plastic cages $(18.5 \times 29.2 \times 12.7 \mathrm{~cm}$ high) fitted with galvanized wirebar tops. Approximately $2 \mathrm{~cm}$ of aspen bedding material covered the cage bottoms. All mice had free accss to Purina Mouse Chow throughout the study, with unflavored tap water available ad lib for at least 2 weeks prior to the beginning of baseline drinking.

Laboratory temperature was thermostatically set at $24^{\circ} \mathrm{C}$ $\left( \pm 2^{\circ} \mathrm{C}\right)$, with overhead fluorescent strip lighting cycled on at $0700 \mathrm{~h}$ and off at $1900 \mathrm{~h}$.

\section{Procedure}

On Day 1 all animals were introduced to baseline drinking by removing their water bottles (at approximately $1200 \mathrm{~h}$ ) until the same time on Day 2, when all animals were given access to unflavored tap water for $10 \mathrm{~min}$. Specifically, pairs of calibrated $(.1-\mathrm{ml})$ bottles fitted with stainless steel spouts were inserted into the central portion of each cage top, allowing the spout tips to be approximately $3 \mathrm{~cm}$ apart. One of the bottles for each animal was filled with plain tap water; the other was empty. Right-left cage positions of the full bottles for all mice were determined at random for each 10 -min baseline drinking session. Subsequent to the allotted $10 \mathrm{~min}$ of drinking, the bottles were removed, and the amounts consumed were determined and recorded for each mouse. These 10-min daily baseline drinking sessions were continued until a total of 24 measures were taken (Days 2-25). After the amounts of water consumed were determined and recorded on Day 25, each animal was removed from its home cage, weighed, and returned. These weights were used for the calculation of drug-injection doses.

Conditioning day (Day 26) consisted of presenting a freshly prepared aqueous sucrose solution ( $20 \%$, weight/volume) in both drinking bottles to all animals for $10 \mathrm{~min}$. Following the 10-min drinking period, a 30-min interval was allowed to elapse, after which animals received one of three injections according to a random determination. Group $S$ animals (16 total, 8 per sex) were injected with Sernyl ${ }^{\circledR}$ (phencyclidine hydrochloride, Bio-Ceutic Laboratories) at an intensity of $10 \mathrm{mg} / \mathrm{kg}$. Group K animals (16 total, 8 per sex) received an injection of Ketase ${ }^{\circledR}$ (ketamine hydrochloride, Bristol Laboratories) at a dose of $10 \mathrm{mg} / \mathrm{kg}$. Finally, Group C (16 total, 8 per sex) received an equivalent-by-weight control injection of $.9 \%$ normal saline. All injections were given intraperitoneally, using 26-guage .5-in. needles.

Prior to aversion testing, all animals were allowed to recover by returning them to plain water baseline drinking for 2 days (Days 27 and 28). Again, the one full, one empty drinking bottle procedure was used, with bottle positions randomized across groups.

Days 29-32 were test days of 10 min duration, with each mouse having a simultaneous choice of drinking from two bottles: one filled with the sucrose solution, the other filled with unflavored tap water. Cage placements of the sweet bottles followed a RLLR counterbalancing for all animals on each test day.

Animals remained in their home cages at all times except for weighing, injecting, and bedding material changes.

\section{RESULTS}

Across the 4 days of preference testing, animals injected with either ketamine or phencyclidine displayed significant conditioned taste aversions relative to the saline-injected controls.
Table 1

Mean Sucrose Preference Scores as a Function of Drug Injection

\begin{tabular}{lrrrr} 
& \multicolumn{4}{c}{ Test Session } \\
\cline { 2 - 5 } \multicolumn{1}{c}{ Group } & \multicolumn{1}{c}{1} & \multicolumn{1}{c}{2} & \multicolumn{1}{c}{3} & \multicolumn{1}{c}{4} \\
\hline Phencyclidine & 6 & 5 & 7 & 7 \\
Ketamine & 11 & 10 & 19 & 24 \\
Saline & 67 & 75 & 76 & 68 \\
\hline
\end{tabular}

For statistical analysis, each animal's consumption of sucrose and plain water for each test day was converted to a sucrose preference score (SPS) using the following formula: amount of sucrose consumed divided by total fluid consumed times 100. Mean SPSs for the three groups across the 4 days are shown in Table 1 .

A two-factor analysis of variance (drug by trials) with repeated measures on trials was performed on the SPSs for individual animals across the 4 days of preference testing. The ANOVA indicated a significant drug effect $[F(2,180)=159.88, p<.001]$, with no reliable effect of trials or interaction ( $F<1$ in each case). A Newman-Keuls test revealed that the ketamine- and phencyclidine-injected groups evidenced significantly ( $p<.05$ in each case) reduced SPSs when compared to the saline-injected controls on each of the 4 test days. Although not attaining statistical significance, a possible extinction effect was observed in the ketamine group from Day 2 to Day 4 of preference testing. This increase in sucrose preference did, however, result in a significant difference on Day 4 between the two drug-injected groups (Newman-Keuls, $\mathrm{p}<.05$ ).

Finally, no reliable preaversion differences existed between groups for animal weights or plain water consumption on the last baseline day [respectively, $F(2,45)<1$ and $F(2,45)=1.0$, n.s.] or for sweet water consumption on conditioning day $[\mathrm{F}(2,45)<1]$.

\section{DISCUSSION}

As can be seen in Table 1, both phencyclidine and ketamine produced very powerful aversions to sucrose, although a nonsignificant trend suggesting extinction begins to appear in the ketamine group on Test Days 3 and 4. This trend could be explained by the fact that ketamine is only $10 \%$ as potent (in terms of its anesthetic properties) as phencyclidine (Domino, Chodoff, \& Corssen, 1965). Interestingly, the aversion evidenced by the phencyclidine group is much stronger than for other drugs such as caffeine $(120 \mathrm{mg} / \mathrm{kg})$, methapyrilene $(5 \mathrm{mg} / \mathrm{kg})$, or $\mathrm{LiCl}(30 \mathrm{ml} / \mathrm{kg}$ of a .15 -molar solution). These three drugs were used to condition aversions in mice using acquisition procedures that were virtually identical to the present study (Etscorn \& Taylor, Note 3).

It is also noteworthy that phencyclidine at $1 \mathrm{mg} / \mathrm{kg}$ produced no taste or visually mediated aversions in adult rhesus monkeys, although drug-induced debilitation lasted for a minimum of $3 \mathrm{~h}$ (Wilcoxon \& Etscorn, Note 1; Wilcoxon et al., Note 2). On the other hand, $10 \mathrm{mg} / \mathrm{kg}$ in mice produces only minor ataxia of relatively short duration, while $12 \mathrm{mg} / \mathrm{kg}$ produces, in addition to marked ataxia, pronounced head-twitching along with a fine motor tremor. Parenthetically, Corne and Pickering (1967) have suggested that head-twitching in mice is quite sensitive to drugs that are hallucinogenic in man.

Finally, the observation that mice readily acquire powerful phencyclidine-induced aversions, while rhesus monkeys have 
failed to do so in several attempts (Wilcoxon \& Etscorn, Note 1) may be reconciled somewhat by the finding that humans of ten display a retrograde amnesia for the circumstances of ingestion (Peterson \& Stillman, 1978). This amnesic effect may be explained due to the proposed action of the dissociative anesthetics upon the cerebral cortex (Goodman \& Gillman, 1975). Therefore, mice, having a less developed cortex (lissencephalic) relative to rhesus monkeys, may be spared from the disruptive amnesic effects.

\section{REFERENCE NOTES}

1. Wilcoxon, H. C., \& Etscorn, F. Failure to demonstrate illness-induced aversions to visual cues in rhesus monkeys. Paper presented at the Southeastern Psychological Association, New Orleans, 1976.

2. Wilcoxon, H. C., Etscorn, F., Czaplicki, J., \& Drake, D. I. Illness-induced aversion based on visual cues from the environment: Replication and extension. Paper presented at the Southern Society for Philosophy and Psychology, Nashville, Tennessee, April 1978.

3. Etscorn, F., \& Taylor, R. Research in progress. New Mexico Tech, Socorro, New Mexico, 1979.

\section{REFERENCES}

Allen, M. R., \& Young, S. J. Phencyclidine-induced psychosis. American Journal of Psychiatry, 1978, 135, 1081-1083.

BERGER, B. D. Conditioning of food aversions by injections of psychoactive drugs. Journal of Comparative and Physiological Psychology, 1972, 81, 21-26.

Braun, J. J., \& McIntosh, H., JR. Learned taste aversions induced by rotational stimulation. Physiological Psychology, 1973, 1, 301-304.

Cappell, H. D., \& LeBlanc, A. E. Conditioned aversion to saccharin by single administrations of mescaline and damphetamine. Psychopharmacologia, 1971, 22, 352-356.

Cappell, H. D., \& LeBlanc, A. E. Gustatory avoidance conditioning by drugs of abuse: Relationships to general issues in research on drug dependence. In N. W. Milgrim, L. Krames, \& T. M. Alloway (Eds.), Food aversion learning. New York: Plenum Press, 1977.

Cappell, H. D., LeBlanc, A. E., \& Endrenyi, L. Aversive conditioning by psychoactive drugs: Effects of morphine, alcohol, and chlordiazepoxide. Psychopharmacologia, 1973, 29, 239-246.

Corcoran, M. E. Role of drug novelty and metabolism in the aversive effects of hashish injections in rats. Life Sciences, 1973 12, 63-72.

Corcoran, M. W., Bolotow, I., Amit, Z., \& McCaughran, J. A., JR. Conditioned taste aversions produced by active and inactive cannabinoids. Pharmacology, Biochemistry, and Behavior, 1974, 2, 725-728.

Corne, S., \& Pickering, R. A possible correlation between druginduced hallucinations in man and a behavioral response in mice. Psychopharmacologia, 1967, 11, 65-78.

Domino, E. F., Chodoff, P., \& Corssen, G. Pharmacologic effects of CI-582, (2-(p-chlorophenyl)-2-methylamino cyclohexanone) a new dissociative anesthetic, in man. Clinical Pharmacology, 1965, 6, 279.

Eastman, J. W., \& Cohen, S. N. Hypertensive crisis and death associated with phencyclidine poisoning. Journal of the American Medical Association, 1975, 231, 1270-1271.

Faraber, P. D., Gorman, J. E., \& Reid, L. D. Morphine injections in the taste aversion paradigm. Physiological Psychology, 1976, 4, 365-368.

Garcia, J., Kimeldorf, D. J., \& Koelling, R. A. Conditioned aversion to saccharin resulting from exposure to gamma radiation. Science, 1955, 122, 157-158.

Garcia, J., \& Koelling, R. A. A comparison of aversions induced by X-rays, toxins, and drugs in the rat. Radiation $\mathbf{R e}$ search Supplement, 1967, 7, 439-450.

Goodman, L. S., \& Gillman, A. The pharmacological basis of therapeutics (5th ed.). New York: Macmillan, 1975.

Goudie, A. J., Dickins, D. W., \& Thorton, E. W. Cocaineinduced conditioned taste aversions in rats. Pharmacology, Biochemistry \& Behavior, 1978, 8, 757-761.

Kessler, Jr., G. F., Demers, L. M., Berlin, C., \& Brennan, R. W. Phencyclidine and fatal status epilepticus. New England Journal of Medicine, 1974, 291, 979. (letter)

Liden, C. B., Lovejoy, F. H., \& Costello, C. E. Phencyclidine (Sernylan) poisoning. Pediatric Pharmacology and Therapeutics, 1975, 234, 513-516.

Nachman, M., Lester, D., \& LeMagnen, J. Alcohol aversion in the rat: Behavioral assessment of noxious drug effects. Science, 1970, 168, 1244-1246.

Peterson, R. C., \& Stillman, R. C. Phencyclidine: A review. Rockville, Md: National Institute on Drug Abuse, 1978.

RAINey, J. M., JR., \& Crowder, M. K. Prevalence of phencyclidine in street drug preparations. New England Journal of Medicine, 1974, 290, 466-467.

(Received for publication April 11, 1979.) 